\title{
TRENDS OF INTERNATIONAL LABOR MIGRATION IN THE MODERN LABOR MARKET
}

\author{
Tymoshyk V. Y. \\ Zaporizhia National University, Ukraine, 69600, \\ Zaporizhzhya, Zhukovsky str, 66 \\ vaileria1306@rambler.ru \\ ORCID:0000-0003-0181-2898
}

Key words:

migration, international migration, tendencies of international labor migration, labor force, wages, demography, population, causes, consequences.
In recent decades, the impact of international migration on world economic and political processes has increased significantly. Today, international labor migration of the population is one of the most important components of modern processes in the world economy, along with its other components, such as the movement of capital, goods, technologies and information. The globalization of the world economy has led to the emergence of new trends in the processes associated with the international migration of labor, requiring scientific study. The article deals with the modern processes of international labor migration. Methods of statistical analysis, analysis of domestic and foreign scientific literature, synthesis of the data obtained are used. The main trends of international labor migration are investigated, such as the increase in the demographic significance of international migration in the demographic development of economically developed countries, the growth of illegal migration, the increase in the composition of migration flows of highly qualified workers and the share of women in the number of international migrants. The article analyzes the economic consequences of the impact of international labor migration on the economies of exporting countries and importing countries of labor resources. International labor migration confirms the fact that countries are dependent on each other. Thus, the negative economic and political changes taking place in the country only negatively affect the flow of international migration. International migration is dependent on scientific and technological progress and the degree of development of transnational corporations, which together create the prerequisites for the free movement of labor from one country to another. Application area. Analysis of flows of international migration confirms the need for countries to work in the field of international law to resolve issues of movement of labor, especially taking into account contemporary world problems. The globalization of the world economy at the present stage has led to the emergence of new trends in the processes associated with the international migration of labor. They are associated with the globalization of world migration flows and the involvement of the population of most countries in this process; an increase in the demographic importance of international migration in the demographic development of economically developed countries; the growth of illegal migration; an increase in the composition of migration flows of highly qualified workers; an increase in forced migration and an increase in the proportion of women in the number of international migrants. The main factor of international labor migration, which has a significant impact on the economies of the countries of origin of migrants, is the flows of migrant remittances, which make a significant contribution to the GDP of countries exporting labor resources, are a valuable source of foreign exchange for governments and play a role in stabilizing the current account of the payment balance. The second most important factor is the positive impact of workers leaving labor markets in labor-abundant countries, since workers leaving abroad reduce unemployment, improve the labor market, and reduce social tensions in the country.

\section{ТЕНДЕНЦІЇ МІЖНАРОДНОЇ ТРУДОВОЇ МІГРАЦІЇ НА СУЧАСНОМУ РИНКУ ПРАЦІ}

\section{Тимошик В. Ю.}

Запорізький національний університет

Україна, 69600, м. Запоріжжя, вул. Жуковського, 66

\begin{abstract}
Ключові слова: міграція, міжнародна міграція, тенденції міжнародної трудової міграції, робоча сила, заробітна плата, демографія, населення, причини, наслідки.
\end{abstract}

В останні десятиліття вплив міжнародної міграції на світові економічні і політичні процеси суттєво зросла. Сьогодні міжнародна трудова міграція населення - одна 3 найважливіших складових сучасних процесів в світовому господарстві поряд з іншими його компонентами, такими як рух капіталу, товарів, технологій та інформації. Глобалізація світової економіки призвела до появи нових тенденцій в процесах, пов'язаних з міжнародною міграцією робочої сили, що вимагають наукового вивчення. У статті розглянуті сучасні 
процеси міжнародної трудової міграції Використано методи статистичного аналізу, аналізу вітчизняної та зарубіжної наукової літератури, синтезу отриманих даних. Досліджено такі основні тенденції міжнародної трудової міграції, як збільшення демографічного значущості міжнародної міграції в демографічному розвитку економічно розвинених країн, зростання нелегальної міграції, збільшення в складі міграційних потоків висококваліфікованих працівників i частки жінок в чисельності міжнародних мігрантів. У статті проаналізовані економічні наслідки впливу міжнародної трудової міграції на економіку країн-експортерів і країнімпортерів трудових ресурсів. Міжнародна міграція робочої сили підтверджує факт залежності країн одна від одної. Таким чином доведено,що негативні економічні і політичні зміни, що відбуваються в країні, тільки негативно позначаються на потоці міжнародної міграції. Міжнародна міграції має залежність від НТП і ступеня розвитку транснаціональних корпорацій, які в сукупності створюють передумови для вільного переміщення робочої сили 3 однієї країни в іншу. Галузь застосування. Аналіз потоків міжнародної міграції підтверджує необхідність роботи країн у галузі міжнародного права для врегулювання питань переміщення робочої сили, особливо з урахуванням сучасних світових проблем.

\section{Problem statement}

Population of planet constantly moves in the searches of the best life for itself and families. A migratory stream of population is one of main forms of globalization, forming of transnational labour-markets, creation of single educational, cultural, language space, attaching of all layers of population to the results of civilization progress. For young people on the first place an economic factor and ambitiousness stand in relation to the construction of career. Exactly these reasons of labour migration in the world змушують the most active part of population of capable of working age to abandon the countries. Foreign employers are most interested by people ready to work in those directions of economy, where own specialists are not or wherever locals wish to work through a small on their opinion acuests.

\section{Analysis of recent studies and publications}

The attention of many experts and researchers is focused on three issues. The first is the nature of migration: causes and consequences, benefits and losses for the country. This problem is solved by EM Libanova [2], Nadtochiy AO [6]. At the same time, a particularly sharp controversy revolves around benefits and losses, with an emphasis on the country's losses from labor migration of its population. The second problem is the scale of Ukrainian labor migration, dynamics and forecasts. Astakhova OV [7] notes that the sharpness of the discussion is largely due to the lack of reliable information even on the quantitative and regional characteristics of migration processes, not to mention the qualitative and professional estimates of the size of this phenomenon. The third problem is the amount of money earned by Ukrainian labor emigrants abroad and the receipt of funds in Ukraine by families and relatives of migrant workers. This problem is considered in the works of Pikulyk O. I. [8], Angelko I. [4]. There is a lack of truthful basic information, so there are not only discussions, but also disputes about how much migrants earn and how much they send or bring to Ukraine.

The purpose of the article is to identify and analyze the main trends of international labor migration and its economic consequences.

\section{Presentation of the main material}

The main reason for labor migration is the uneven economic development of different countries. This is due to the fact that in some countries there is a surplus of labor, which affects the rate of economic growth, and in others, on the contrary, there is a shortage. The significant difference in wages encourages people to migrate to countries where it is much higher than in their homeland. On average, there are three dependents per migrant, and many leave to provide for their families. For countries from which the working population leaves, this phenomenon is positive in the sense that the unemployment rate decreases (all those labor resources that can not find work at home usually find it in the country to which they emigrated), poverty, rising standard of living due to remittances. For importing countries, the positive aspects of international migration are increased competitiveness, elimination of labor shortages, and migrants pay taxes to the country in which they are located. Many companies, by hiring foreign workers, avoid bankruptcy and liquidation, reduce costs by providing low wages to foreign workers, because for this money many locals do not agree to work. International migration is a global phenomenon, the scale of which is growing every year, in In 2015, it reached 243.7 million people. As of the beginning of 2020, the number of international migrants amounted to 272 million people. while $74 \%$ of them are migrant workers (Fig. 1). 


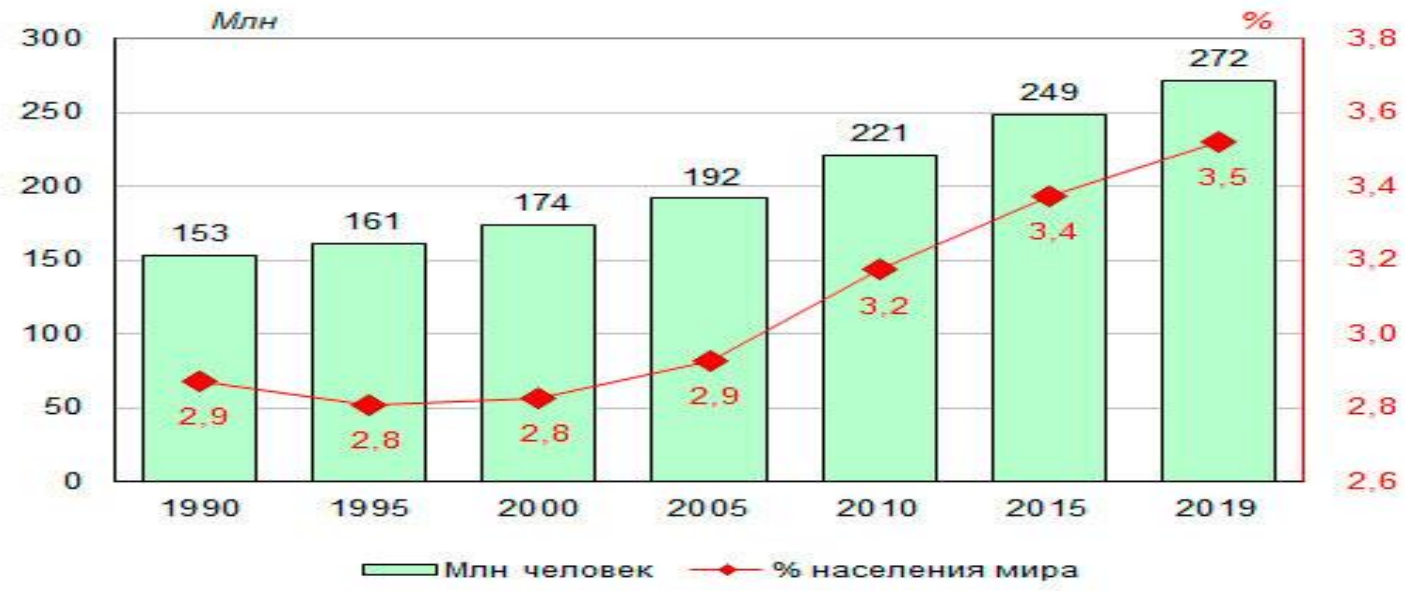

Figure 1. Dynamics of the number of international migrants, [1].

Today, many migrants take advantage of the global economy to increase their mobility as highly skilled professionals or entrepreneurs. The level of qualification in the processes of international labor migration plays an important role, as the countries of migration seek to attract highly qualified personnel, establishing favorable rules of entry and residence of such workers. Modern migration processes are characterized by the emergence of new forms of mobility, such as reverse or circular migration. The barrier between migration and tourism is becoming blurred as some people travel as tourists to check out potential migration routes. An important factor in migration today is family migration, due to moving to work or residence in another country of spouses, children and other relatives of previous primary migrants. Family migration also contributes to the development of migration networks connecting the countries of departure and the countries of arrival of international migrants. Migration can change demographic, economic and social structures and create a new cultural diversity that often calls into question national identity. Global cultural exchange, facilitated by modern means of communication and the distribution of print and electronic media, can also contribute to the growth of migration aspirations. Motives for migration can be of different nature: political, economic, environmental, military.

You can identify the following causes of labor migration:

- high unemployment, lack of jobs;

- mismatch of the level of wages with people's expectations;

- imbalance between available vacancies and the level of qualification of job applicants;

- complication of the political situation

- man-made disasters;

- economic instability.

An important factor influencing migration is the demographic processes of the modern world and the exacerbation of financial problems associated with declining birth rates and population aging in industrialized countries. The imbalance in world population growth is expressed in accelerating population growth in developing countries and lowering the birth rate below the level of natural reproduction in developed countries. The bulk of 100 this increase is in Asia and Africa, where high birth rates due to infant mortality and poor birth control programs lead to high annual population growth rates. On the contrary, the birth rate in Western industrialized countries is declining. Declining birth rates in a number of industrialized countries are helping to increase the demand for migrant work in low-paid jobs. This is due to the fact that as incomes and living standards increase in these countries, local workers try to avoid low-paid and lowskilled jobs, making them dependent on migrant workers. In sectors such as agriculture, construction, cleaning, catering, hotel services, tourism, childcare, household services and entertainment, there are many jobs that indigenous people are reluctant to find.

The changing gender composition of migration in recent decades has been associated with an aging population in developed and some developing countries, leading to an increase in demand for care work, much of which was previously performed by women. The feminization of migration is also characteristic of migratory flows of highly skilled labor. Although women still face unequal access to university education in many developing countries, the proportion of migrant women with higher education is $17.6 \%$, compared with $13.1 \%$ of male migrants. The growth rate of the number of skilled migrant women exceeds the growth rate of the number of lowskilled migrant women in the vast majority of regions. However, despite the growing number of highly skilled migrant women in labor migrants, they are more likely than skilled male migrants to find jobs that do not match their level of education and qualifications.

Employers of countries - importers of labor are most interested in people who are willing to work in those areas of the economy where there are no own specialists or where locals do not go because of low wages. Each country has its own specialties. But mostly you need service staff, teachers, programmers. Most migrants from the CIS countries are civil engineers and doctors. Demanded and working specialties (security guards, railroad workers, builders). The main focus is on the size of wages. The highest earnings are in the UK and Scandinavia, but the difficulty is that these countries are reluctant to accept migrants. Earnings are quite high in Germany, the Netherlands and France (the average salary is 2,200 €per month). At the same time, earnings in 
countries such as Lithuania and Bulgaria reach an average of 300-450€. In Poland, Slovakia, Latvia, a simple worker is paid about $500 €$, and people with higher education 800 $1200 €$ (depending on the profession). As for Ukraine, the dynamics are the same here. The country lacks construction workers due to low wages. Ukrainian construction companies offer a salary of $12,000 \mathrm{Z}$, while in Poland they offer 20,000 $Z$ (starting salary) for the same work. For more prestigious specialties salaries are even higher. Accordingly, young people, even with secondary education, are interested in labor migration in order to earn many times more than at home.

Many experts point out that the duration of work abroad for the vast majority of Ukrainian workers returning to Ukraine does not exceed one year, but $29 \%$ worked for more than a year and $14 \%$ for several years [2,3]. This trend in terms of short-term migrants is typical of neighboring Poland and the Czech Republic. At the same time, a third of working Ukrainians in Italy have not returned home for more than a year. The duration of one trip of an illegal part of Ukrainian labor migrants does not exceed 3 months, but most of them leave several times a year. And if earlier the majority of labor migrants were observed mainly in the western regions of Ukraine, now this trend has spread to the central and southern regions. The experience of working abroad is obviously positive for the majority - $71 \%$ of workers would like to work outside Ukraine again in the future [2,3]. The total number of Ukrainian labor migrants who work abroad at the same time ranges from 1.5 to 5.0 million people.

Basically, migrant workers complain that it is difficult for them to restore emotional relationships with relatives, to find a "social niche" in a new life, a job that is adequate to their needs and desires. Thus, there is a significant disproportion between the number of migrants who declare their desire to return home (it is 65-75\%) and the number of those who realize this desire (20-25\%) [4]. According to the National Bank of Ukraine, which calculates the volume of private transfers when calculating the country's balance of payments, they grew steadily (except during the global financial and economic crisis) and in 2013 exceeded $\$ 8.5$ billion. USA. However, in 2014 the amount of remittances decreased significantly (by $24 \%$ ), which was a consequence of security, political and economic troubles in Ukraine, as well as the crisis of its financial system. Some improvement in the domestic situation, as well as the intensification of labor migration abroad led to the resumption of growth in the amount of private transfers (Fig. 2), which in 2018 reached 11.1 billion dollars. US, which corresponds to $8.5 \%$ of GDP. The amount of remittances more than quadrupled the amount of foreign direct investment. If earlier the main country of origin of transfers was Russia, where a third of all transfers came, then over the last five years the share of Russia has been declining and in 2018 was less than $10 \%$ (US \$ 1.09 billion). In contrast, in 2018, Ukraine received $32.8 \%$ of all transfers from Poland ( $\$ 3.6$ billion). The volume of remittances from the Czech Republic almost doubled compared to the previous year (7.6\% of all remittances, or USD 846 million). Through informal channels, ie the method of transferring cash or valuables from one household to another, in 2013 Ukraine received $14 \%$ of all transfers, and in 2018 - almost half [5].

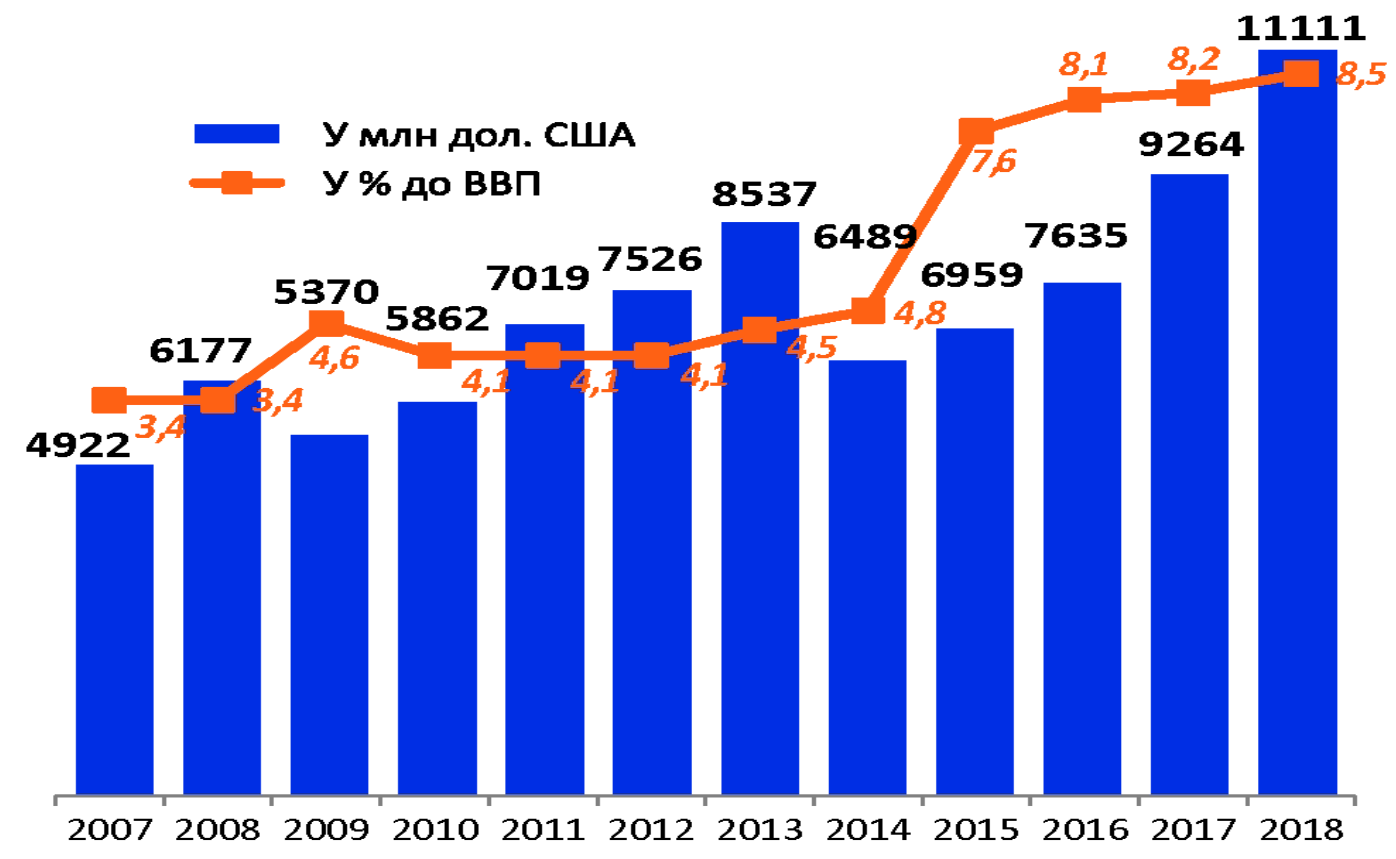

Figure 2. Private transfers to Ukraine for the period 2007-2018, [5] 
Consider in more detail the consequences of remittances due to their ambiguous impact:

- increase the solvency of certain categories of citizens, and as a result increases the aggregate demand for certain goods and services, which serves as a source of development of relevant industries;

- stimulate imports through the propensity to consume imported goods and services;

- have a stable character, which can be considered as a reliable source of foreign exchange;

- ble to cover the trade deficit of Ukraine;

- if they are set aside for savings, they are a source of investment in the country's economy.

However, according to experts, in Ukraine the propensity to save is low (the share of savings in households is less than $10 \%$, which indicates a low standard of living), and therefore the mechanism of "savings - investment" remains unaffected [6]. At the same time, such positive consequences of labor migration are not unambiguous. The increase in the money supply leads to higher prices, imported goods create competition with domestic goods. Consumption-oriented migrants' money has little effect on investment or credit use. The impact of earnings abroad on the development of small business is extremely modest due to the unfavorable tax situation, lack of cheap loans, difficulties with business registration, disbelief of citizens in the prospects of small business [7].

\section{Conclusions}

The globalization of the world economy at the present stage has led to the emergence of new trends in the processes associated with international labor migration, which can be reduced to the following. As the number of international migrants grows faster than the total population, their share of the world's population is increasing. Developed countries with a declining population, which consists mainly of older people, will face difficulties in providing basic public goods and services, such as health care, housing, transport and tourism. Demographic trends, leading to an aging workforce and an increasing share of retirees in developed countries, are forcing developed countries to use migration as a tool to address emerging demographic challenges. Labor migration for Ukraine today is a complex and large-scale phenomenon, which has mostly negative consequences: we are losing young people and highly qualified specialists, for training, education and training of which the state has spent a lot of money, and they will implement their knowledge outside our country. Thus, the mass exodus of Ukrainians to work in neighboring countries contributes to the growth of the economy and prosperity of these countries, but at the same time worsens the economic, demographic and social situation in Ukraine. Legal migrant workers pay taxes in those countries where they work, respectively, the problem with the payment of pensions is exacerbated, as Ukraine still has a joint pension system [8]. Migration should be part of Ukraine's strategic policy planning. As there are no shortterm tools to stop the current outflow, Ukraine should try to adapt to net emigration and take advantage of it, mitigating the negative effects it causes.

\section{References}

1. Doklad o migracii v mire (2020), [ World Migration Report ]. Retrieved from: https://publications.iom.int/system/files/pdf/wmr_2020_ru_ch_1.pdf [in Russian]

2. E. M. Libanova (2020), Zovnishni trudovi mihratsii ukraintsiv: masshtaby, prychyny, naslidky [External labor migration of Ukrainians: scale, causes, consequences]. Retrieved from: https: // www. researchgate. Net / publication /339335984 [in Ukrainian]

3. Nastroi sered ukraintsiv-zarobitchan(2017), [Sentiment among Ukrainian workers].Retrieved from: http: // ratinggroup. ua / research / Ukraine / nastroeniya_sredi_ukraincev-zarobitchan.html [in Ukrainian]

4. I. Anhelko (2014), Sotsialno-ekonomichni naslidky vplyvu mizhnarodnoi mihratsii robochoi syly na dobrobut naselennia Ukrainy [Socio-economic consequences of the impact of international labor migration on the welfare of the population of Ukraine ], Visnyk Ternopilskoho natsionalnoho ekonomichnoho universytetu- Bulletin of Ternopil National Economic University, 2, $65 \square 72$ [in Ukrainian]

5. Mihratsiia v Ukraini. Tsyfry i fakty (2020), [Migration in Ukraine. Facts and figures ]. Retrieved from: file://C:/Users/uzver/AppData/Local/Temp/iom-ukraine_facts-ukr_2019-1 [in Ukrainian]

6. A. O. Nadtochii (2015), Prychyny zovnishnoi trudovoi mihratsii ta otsinka yii naslidkiv dlia ekonomiky Ukrainy [Causes of external labor migration and assessment of its consequences for the economy of Ukraine], Teoriia ta praktyka derzhavnoho upravlinnia - Theory and practice of public administration, 1, 106-113 [in Ukrainian]

7. O. V. Astakhova (2012), Trudova mihratsiia ta yii sotsialno -ekonomichni naslidky [Labor migration and its socioeconomic consequences], Rynok pratsi ta zainiatist naselennia - Labor market and employment, 1, 8-11 [in Ukrainian]

8. O. I. Pikulyk (2020), Prychyny, osoblyvosti na naslidky trudovoi mihratsii Ukrainy [Causes, features on the consequences of labor migration of Ukraine ], Ekonomika ta suspilstvo - Economy and society, 21,16-20 [in Ukrainian] 